\title{
IMPLEMENTASI SISTEM INFORMASI AKUNTANSI PADA KOPERASI ANGGREK II JORONG PANDAN KECAMATAN TANJUNG RAYA KABUPATEN AGAM DIDUKUNG DENGAN MENERAPKAN APLIKASI SISTEM MULTIUSER PADA BAHASA PEMROGRAMAN JAVA DAN DATABASE MYSQL
}

\author{
Hari Marfalino ${ }^{1}$ \\ Guslendra ${ }^{2}$ \\ Azlina Mega Sari ${ }^{3}$
}

\begin{abstract}
Savings and loan activities at the cooperative is one of the routine activities. In accordance with the role of cooperatives that aim to maintain the welfare of its members. Management of bad savings and loan activities will lead to chaos in the operational activities of the cooperative. Based on the research that has been done on Cooperative Orchid II Jorong Pandan using field research methodology, library research and laboratory research, it is known that the financial data processing system is still done manually and simply. With the design of Accounting Information Systems are supported Java programming language will provide a better solution to the problems encountered. The level of error in doing the calculations can be minimized, the information produced more accurately and the data can be stored safely.
\end{abstract}

Keywords: SIA, Cooperatives, Services.

\section{INTISARI}

Kegiatan simpan pinjam pada koperasi merupakan salah satu aktivitas yang rutin dilakukan. Sesuai dengan peran koperasi yang bertujuan untuk menjaga kesejahteraan anggotanya. Pengelolaan kegiatan simpan pinjam yang kurang baik akan mengakibatkan kekacauan dalam kegiatan operasional koperasi. Berdasarkan penelitian yang telah dilakukan pada Koperasi Anggrek II Jorong Pandan dengan menggunakan metodologi penelitian lapangan, penelitian pustaka dan penelitian laboratorium, maka diketahui bahawa sistem pengolahan data keuangan masih dilakukan secara manual dan sederhana. Dengan perancangan Sistem Informasi Akuntansi yang didukung bahasa pemrograman Java akan memberikan solusi yang lebih baik terhadap masalah-masalah yang dihadapi. Tingkat kesalahan dalam melakukan perhitungan dapat diperkecil, informasi yang dihasilkan lebih akurat serta data-data dapat disimpan dengan aman.

Kata Kunci : SIA, Koperasi, Jasa.

$\overline{1,2,3}$ Universitas Putra Indonesia (UPI) YPTK Padang 


\section{PENDAHULUAN \\ Latar Belakang}

Koperasi Anggrek II

merupakan salah satu jenis koperasi simpan-pinjam yang berada di Jorong Pandan. Pinjaman atau kredit tersebut disertai dengan bunga yang ringan. Pinjaman tersebut bertujuan demi produktivitas atau kesejahteraan para angotanya. Sekaligus sebagai gerakan ekonomi rakyat yang berdasarkan prinsip koperasi, yang berdasarkan atas asas kekeluargaan.

Pengelolaan keuangan pada Koperasi Anggrek II ini masih menggunakan sistem konvensional yaitu menggunakan buku dan Microsoft Excel. Dengan jumlah anggota yang ada di Koperasi Anggrek II cara ini kurang efektif karena transaksi simpan pinjam yang terjadi semakin tinggi sehingga penghitungan juga semakin banyak. Dalam pengelolaan akuntansi juga membutuhkan ketelitian karena banyak pengulangan penulisan yang membutuhkan ketelitian dan pemborosan waktu pengerjaan.

Untuk mengatasi masalah tersebut, diperlukan suatu sistem informasi akuntansi pada Koperasi Anggrek II yang mampu membantu seluruh proses pengelolaan simpanan dan pinjaman hingga menghasilkan laporan akuntansi manajemen secara langsung.

Berdasarkan uraian di atas dan didorong oleh keinginan untuk membahas masalah ini, maka penulis tertarik untuk membahasnya dalam suatu penelitian yang berbentuk skripsi dengan judul : "Implementasi Sistem Informasi Akuntansi pada Koperasi Anggrek II Jorong Pandan Kecamatan Tanjung Raya Kabupaten AgamDidukung dengan Menerapkan Aplikasi Sistem Multiuser pada Bahasa Pemrograman Java dan Database MySQL".

\section{Perumusan Masalah}

Berdasarkan latar belakang penelitian maka dapat diketahui permasalahan-permasalahan yang ada pada Koperasi Anggrek II Jorong Pandan Kecamatan Tanjung Raya Kabupaten Agam dalam melakukan proses pengolahan data keuangan. Permasalahanpermasalahan tersebut adalah :

1. Apakah aplikasi sistem pengolahan data keuangan yang dibangun mampu menghasilkan informasi yang tepat dan akurat?

2. Bagaimana Bahasa Pemrograman JAVA dapat diaplikasikan untuk membangun sebuah Sistem Informasi Akuntansi Koperasi Anggrek II pada Jorong Pandan Kecamatan Tanjung Raya Kabupaten Agam ?

3. Apakah penggunaan Sistem Informasi Akuntansi dapat membantu terhadap prosedur tranksaksi dari pinjaman anggota Koperasi yang akan dilakukan pada Koperasi?

\section{Hipotesa}

Berdasarkan pada perumusan masalah di atas maka penulis mengemukakan hipotesa sebagai berikut :

1. Dengan didukung penggunaan komputer dan penerapan sistem informasi akuntansi diharapkan mampu menghasilkan informasi yang

tepat dan akurat.

2. Dengan digunakannya bahasa pemrograman JAVA dan database MySQL pada proses pengolahan data keuangan Koperasi Anggrek II dapat membantu meningkatkan kinerja dan menghasilkan informasi yang akurat.

3. Dalam melakukan analisa sistem informasi akuntansi dan pengolahan data keuangan, diharapkan dapat memberi informasi atau laporan yang akurat dalam mengambil 
keputusan yang tepat, sehingga masalah-masalah yang berhubungan dengan analisa sistem informasi keuangan pada Koperasi Anggrek II Jorong Pandan Kecamatan Tanjung Raya Kabupaten Agam dapat teratasi.

\section{Ruang Lingkup Penelitian}

Penelitian yang dilakukan haruslah terarah, maka objek yang akan diteliti terletak pada masalah mengenai laporan keuangan simpan pinjam pada Koperasi Anggrek II Jorong Pandan, sehingga laporan atau informasi dari hasil pengolahan data simpan pinjam sangat berguna bagi pimpinan pada Koperasi Anggrek II Jorong Pandan dalam mengambil keputusan.

\section{PENDEKATAN DAN PEMECAHAN MASALAH \\ Tinjauan Umum Koperasi}

Pada dasarnya koperasi merupakan suatu lembaga ekonomi yang penting dan diperlukan. Koperasi merupakan usaha bersama yang berlandaskan asas kekeluargaan untuk meningkatkan kesejahteraan anggotanya. Koperasi berasal dari bahasa Inggris cooperation, cooperative, atau bahasa Latin: coopere, atau dalam bahasa Belanda: cooperatie, cooperatieve, yang kurang lebih berarti bekerja bersama-sama, atau kerja sama, atau usaha bersama atau yang bersifat kerjasama.

Dasar hukum keberadaan koperasi di Indonesia ada dalam pasal 33 UUD 1945 dan UU No.25 tahun 1992 tentang perkoperasian.Yang dimaksud dengan koperasi adalah:

"Badan usaha yang
beranggotakan orang seorang
atau badan hokum koperasi
dengan melaksanakan
kegiatannya berdasarkan prinsip

koperasi, sekaligus sebagai gerakan ekonomi rakyat yang berdasar atas asas kekeluargaan".

Tujuan kopersai sebagaimana dikemukakan dalam pasal 3 UU No.25/1992 adalah sebagai berikut:

"Koperasi bertujuan memajukan kesejahteraan anggota pada khususnya dan pada masyarakat pada umumnya serta ikut membangun tatanan perekonomian nasional dalam rangka mewujudkan masyarakat yang maju, adil dan makmur berdasarkan Pancasila dan UUD 1945". [3]

a. Jenis-jenis Koperasi

Koperasi secara umum dapat dikelompokan menjadi koperasi konsumen, koperasi produsen dan koperasi kredit (jasa keuangan). Koperasi dapat pula dikelompokkan berdasarkan sektor bidang kerja dan usahanya yaitu :

1. Koperasi Simpan Pinjam

Adalah Koperasi yang bergerak dibidang simpanan dan pinjaman untuk Memenuhi kebutuhan dan keperluan ekonomi anggotanya.

2. Koperasi Konsumen Adalah Koperasi beranggotakan para konsumen dengan menjalankan kegiatannya jual beli menjual barang konsumsi.

3. Koperasi Produsen

Adalah Koperasi beranggotakan para pengusaha kecil UKM dengan menjalankan kegiatan pengadaan bahan baku dan penolong untuk anggotanya

4. Koperasi Pemasaran Adalah Koperasi yang menjalankan kegiatan 


\author{
penjualan produk/jasa \\ koperasinya atau \\ anggotanya. \\ 5. Koperasi Jasa \\ Adalah Koperasi yang
bergerak dibidang
jasa lainnya. [5]
}

\section{b. Sumber Dana Koperasi (Jenis- jenis Modal Koperasi)}

Seperti halnya bentuk badan usaha yang lain, untuk menjalankan kegiatan usahanya koperasi memerlukan modal. Adapun modal koperasi terdiri atas modal sendiri dan modal pinjaman.

Modal sendiri meliputi modal sebagai berikut :

1. Simpanan Pokok

Simpanan Pokok adalah sejumlah uang yang wajib dibayarkan anggota

kepada koperasi pada saat masuk menjadi anggota. Simpanan pokok tidak dapat diambil kembali selama yang bersangkutan masih menjadi anggota koperasi. Simpanan pokok jumlahnya sama untuk setiap anggota.

2. Simpanan Wajib

Simpanan wajib adalah jumlah simpanan tertentu yang harus dibayarkan oleh anggota kepada koperasi dalam waktu dan kesempatan tertentu, misalnya tiap bulan dengan jumlah simpanan yang sama untuk setiap bulannya. Simpanan wajib tidak dapat diambil kembali selama yang bersangkutan masih menjadi anggota koperasi.

3. Dana Cadangan

Dana cadangan adalah sejumlah uang yang diperoleh dari penyisihan sisa hasil usaha, yang dimaksudkan untuk pemupukan modal sendiri, pembagian kepada anggota yang keluar dari keanggotaan koperasi, dan untuk menutup kerugian koperasi bila diperlukan.

4. Hibah

Hibah adalah sejumlah uang atau barang modal yang dapat dinilai dengan uang yang diterima dari pihak lain yang bersifat hibah atau pemberian dan tidak mengikat.

5. Adapun Modal-modal koperasi berasal dari sebagai berikut :
a. Anggota dan calon anggota
b. Koperasi lainnya dan/atau anggota yang didasari dengan perjanjian kerjasama antar koperasi.
c. Bank dan lembaga keuangan lainnya yang dilakukan berdasarkan ketentuan peraturan perundang-undangan yang berlaku.
d. Penerbitan Obligasi dan surat utang lainnya yang dilakukan berdasarkan ketentuan peraturan perundang-undangan yang berlaku.

e. Sumber lain yang sah. [5]

\section{c. Sisa Hasil Usaha Koperasi}

SHU menurut UU No.25 Tahun 1992, tentang perkoperasian adalah suatu pendapatan koperasi yang diperoleh dalam satu atahun buku dikurang dengan biaya, penyusutan, dan kewajiban lain termasuk pajak dalam tahun buku yang bersangkutan. SHU setelah dikurangi dana cadangan, dibagikan kepada anggota sebanding jasa usaha yang 
dilakukan oleh masing-masing anggota dengan koperasi, serta digunakan untuk keperluan koperasi, sesuai dengan keputusan Rapat Anggota. Besarnya pemupukan modal dana cadangan ditetapkan dalam keputusan Rapat Anggota. [5]

\section{Alat Bantu dalam Perancangan Sistem}

Dalam melakukan tugas-tugas analisis dan perancangan sistem, para analisis sistem/perancangan sistem biasanya menggunakan peralatan-peralatan bantu. Peralatan bantu ini terutama digunakan untuk menjabarkan sistem dan juga sebagai dokumentasi. Ada beberapa alat bantu untuk perancangan sistem diantaranya adalah Aliran Sistem Informasi, Data Flow Diagram, Entity Relationship Digram, Program Flow Chart dan lain sebagainya.

\section{Sistem Informasi Akuntansi}

Sistem Informasi Akuntansi (Accounting information System) adalah suatu komponen yang bertugas untuk mengumpulkan, menggolongkan, mengolah, menganalisa, dan mengkombinasikan informasi keuangan yang relevan untuk pengambilan keputusan pihak-pihak luar (seperti inspektorat pajak, investor, dan kreditor) dan pihakpihak dalam (terutama manajemen).

Sistem informasi akuntansi itu sendiri dibagi menjadi dua subsistem yaitu:

a. Sistem Informasi Akuntansi Keuangan disusun teutama untuk menghasilkan informasi yang biasanya dalam bentuk laporan keuangan yang ditujukan pada pihak-pihak luar atau pihak-pihak eksternal perusahaan atau organisasi. Umumnya laporan keuangan yang dihasilkan terdiri dari neraca, laporan laba rugi, laporan perubahan modal, dan laporan perubahan posisi keuangan.

b. Sistem Informasi Akuntansi Manajemen adalah penyatuan bagian manajemen yang mencakup penyajian dan penafsiran informasi yang digunakanuntuk perumusan strategi, aktivitas perencanaan dan pengendalian, pembuatan keputusan, optimalisasi penggunaan sumber daya, pengungkapan kepada pemilik dan pihak luar, pengungkapan kepada pekerja, serta pengamanan asset guana menghasilkan informasi untuk pengguna internal, seperti manajer, eksekutif, dan pekerja. [2]

\section{Model Sistem Informasi Akuntansi}

Tugas pengolahan data perusahaan dilaksanakan SIA yang mengumpulkan data yang menjelaskan kegiatan perusahaan, mengubah data tersebut menjadi informasi, serta menyediakan informasi bagi pemakai di dalam maupun di luar perusahaan.

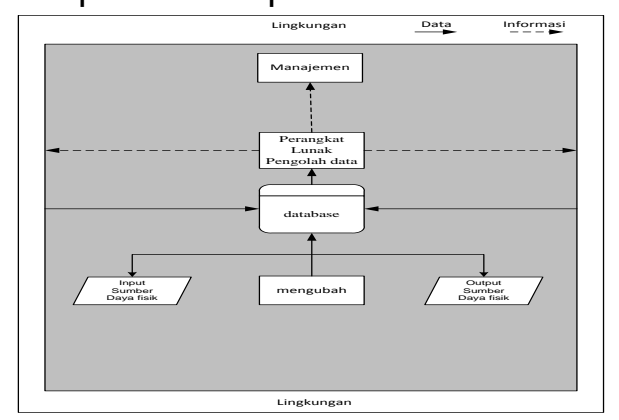

Sumber: (Yakub. 2012. "Pengantar Sistem Informasi". Graha IImu, Yogyakarta : 75)

Gambar 1. Model Sistem Informasi Akuntansi

Elemen input, transformasi dan output dari sistem fisik perusahaan berada di bagian bawah. Data dikumpulkan dasi seluruh sistem fisik dan lingkungan, lalu dimasukkan ke dalam database. Perangkat lunak pengolah data 
mengubah data menjadi informasi untuk manajemen perusahaan serta untuk perorangan dan organisasi didalam lingkungan perusahaan.

\section{Analisa Dan Perancangan Analisa Sistem}

Tahap analisa sistem perlu dilakukan dahulu sebelum tahap perancangan sistem, tahap analisa sistem merupakan tahap yang penting didalam merancang suatu sistem. Analisa sistem dilakukan untuk mengetahui masalah apa yang sebenarnya dihadapi oleh Koperasi Anggrek II saat ini. Tujuan dari analisa terhadap sistem yang lama yaitu untuk mendapatkan solusi yang lebih baik dengan melihat kelemahan-kelemahan dari sistem tersebut.

\section{a. Analisa Sistem yang Sedang Berjalan}

Analisa sistem perlu dilakukan untuk mengetahui dan memahami masalah yang akan dihadapi. Dalam analisa dan perancangan sistem ini, kegiatan yang akan dilakukan adalah menitikberatkan pada penelitian dan penjabaran dari pada sistem yang sedang berjalan untuk mengetahui kelebihan dan kelemahan sistem yang sedang berjalan. Dimana pengolahan data yang dilakukan dengan sistem manual dapat menimbulkan kesulitan-kesulitan dalam menghasilkan informasi yang dibutuhkan.

\section{b. Aliran Sistem Informasi Lama}

Koperasi Anggrek II adalah Koperasi yang bergerak dalam bidang simpan pinjam. Berikut gambaran transaksi yang terjadi pada Koperasi Anggrek II :

1. Anggota akan melakukan pendaftaran sebagai anggota Koperasi dengan mengisi formulir dan melengkapi persyaratan yang sudah ditentukan oleh Koperasi.

2. Karyawan memberikan kartu daftar anggota terhadap anggota yang sudah melengkapi persyaratan untuk menjadi anggota Koperasi.

3. Setelah mendapatkan kartu anggota maka anggota diwajibkan melakukan simpanan pokok.

4. Anggota yang akan melakukan simpan pinjam dengan bagian Koperasi, dengan mengisi surat permintaan pinjaman.

5. Karyawan bertugas mencatat data anggota yang sudah melakukan simpan pinjam, sekaligus membuat laporan anggota yang akan diberikan ke bagian pimpinan.

6. Setiap data anggota akan dimasukkan dalam laporan daftar anggota yang disusun berdasarkan nomor urut, nantinya akan diserahkan pada tim verifikasi dan pimpinan untuk disahkan.

7. Setelah laporan anggota sudah di ACC oleh pimpinan, pimpinan akan memberikan laporan anggota ACC terhadap karyawan.

8. Anggota yang permohonan pinjamannya yang telah di ACC, kemudian dapat mencairkan pinjamannya yang disertai dengan bukti pencairan pinjaman oleh Koperasi.

9. Bukti pencairan pinjaman akan dimasukkan kedalam laporan pinjaman oleh karyawan dan hasil laporan peminjaman akan diberikan kepada pimpinan.

10. Untuk pembayaran pinjaman menggunakan bukti pinjaman yang diserahkan kepada karyawan, yang pada setiap pembayaran akan dicatat dan dibuat bukti pembayarannya.

11. Bukti pembayaran cicilan dari pinjaman salah satunya akan 
diarsipkan oleh Koperasi dan yang lainnya akan diberikan pada anggota.

12. Dari setiap pembayaran cicilan pinjaman akan dibuat laporan pembayarannya untuk diperlihatkan kepada karyawan, yang nantinya akan digunakan untuk rapat anggota tahunan.

13. Karyawan mencatat buku kas, yang mana isi dari buku kas tersebut terdiri atas daftar penerimaan dan pengeluaran kas Koperasi tersebut.

\section{c. Analisa Sistem Pengolahan Data}

Berdasarkan pengamatan yang diakukan pada Koperasi Anggrek II Jorong Pandan Kabupaten Agam maka dapat dijelaskan bagaimana sistem ini berjalan. Adapun analisa input, proses dan output dari sistem tersebut adalah sebagai berikut:

\section{1) Analisa Input}

Dalam melaksanakan suatu proses pegolahan data, diperlukan suatu input dimana bertujuan untuk mengetahui data-data apa saja yang dibutuhkan untuk pemrosesan nantinya oleh sistem. Pada koperasi data input yang digunakan sebagai bahan masukkan adalah data simpan pinjam. Semua elemen-elemen input ini merupakan awal dari proses pengolahan data simpan pinjam yang tersedia hingga data tersebut ditampilkan. Untuk lebih jelasnya tampilan untuk input sistem lama dapat dilihat pada Gambar 2.

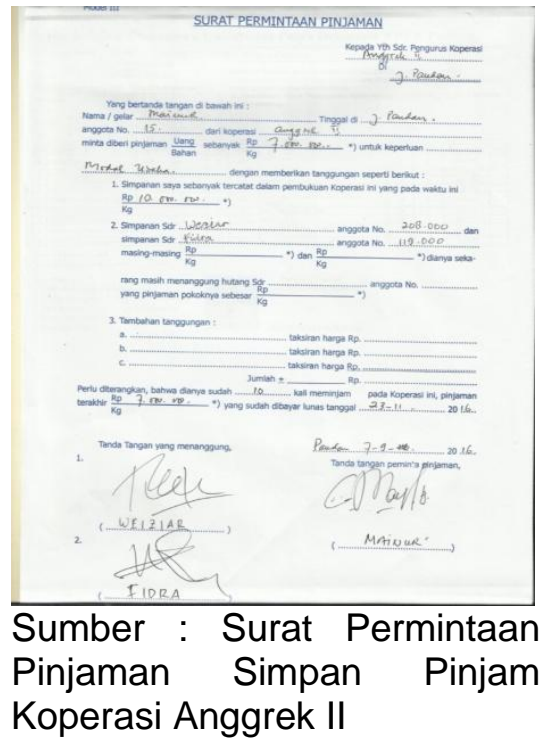

Gambar 2. Surat Permintaan Pinjaman

\section{2) Analisa Proses}

Setelah melakukan penganalisaan terhadap input (masukan) yang diperoleh dari bagian simpan pinjam, disesuaikan dengan daftar keuangan yang diadakan koperasi tersebut, serta daftar permintaan dari anggota sebagai bahan masukan awal, maka selanjutnya dilakukan proses pengolahan data simpan pinjam yang akan dihasilkan berdasarkan input tersebut, adapun proses yang dilakukan adalah sebagai berikut:

a) Setiap proses peminjaman yang terjadi dilakukan pencatatan oleh bagian karyawan. Lalu laporan ini diserahkan ke pimpinan sebagai arsip.

b) Pihak koperasi memberikan kebutuhan simpan pinjam sesuai dengan keinginan anggota dan mencatat keuangannya, lalu bukti simpan pinjam ini sebagai data dalam proses entry data simpan pinjam yang akan menghasilkan laporan simpan pinjam dan 
menyerahkan laporan ke pimpinan.

\section{3) Analisa Output}

Berdasarkan hasil dari input dan proses yang sedang berjalan pada saat ini, maka dilakukan analisa terhadap output yang ada yaitu berupa laporan-laporan yang berhubungan dengan simpan pinjam. Laporan-laporan tersebut dibuat oleh karyawan koperasi tersebut. Dalam pembuatan laporan tersebut dilakukan dengan menggunakan metode manual dimana laporan diisi langsung oleh pegawai sehingga menghasilkan laporan harian. Laporan tersebut selanjutnya diserahkan kepada pimpinan sebagai bahan pertimbangan untuk mengambil suatu keputusan yang diperlukan oleh Koperasi Anggrek II Jorong Pandan.

Dalam hasil penelitian yang telah dilakukan pada sistem informasi akuntanso simpan pinjam pada koperasi, maka dapat didefenisikan beberapa kelemahan sebagai berikut :

a. Pembuatan laporan simpan pinjam yang sering terjadi kekeliruan dalam hasil perhitungannya sehingga pegawai sering melakukan perhitungan pendataan kembali.

b. Perhitungannya masih dilakukan dengan kalkulator dan dicatat pada blangko yang telah disediakan.

c. Seringnya terjadi keterlambatan dalam hasil laporan yang diterima oleh pimpinan.

d. Dalam sistem lama pembuatan laporan masih dicatat secara manual dan juga menggunakan aplikasi Ms. Office Excel.

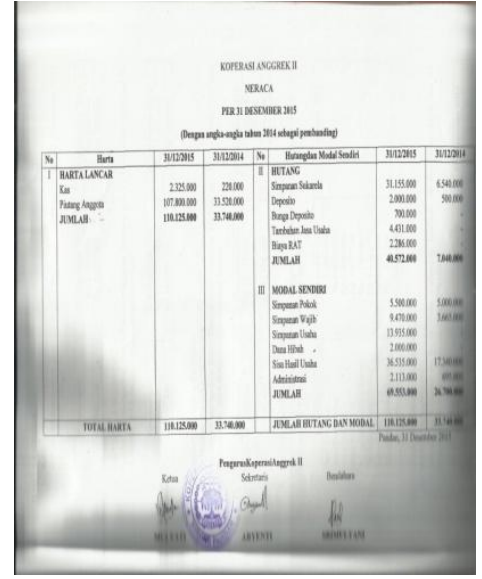

Sumber : Laporan Neraca Koperasi per Desember 2015

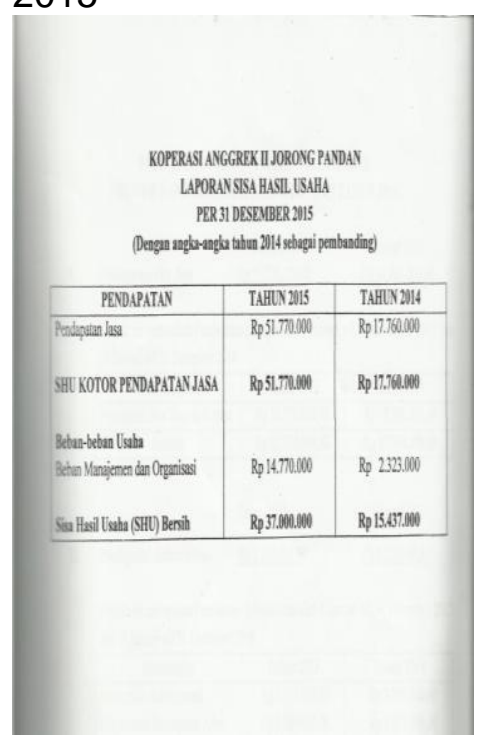

Sumber : Laporan Neraca Koperasi per Desember 2015

Gambar 3. Laporan Neraca Dan Laba/Rugi (SHU) Koperasi

\section{d. Hasil Analisa}

Dari hasil analisa pada Koperasi Anggrek II maka dapat diketahui kelemahan-kelemahan dari analisa sistem informasi lama, diantaranya :

1. Dalam pembuatan laporan masih dilakukan secara manual dan tidak semua data yang ada dalam transaksi dilaporkan.

2. Data yang diinginkan sewaktu-waktu oleh pihak 
yang berkepentingan tidak dapat diperoleh dengan cepat.

\section{Desain Sistem Baru}

Berdasarkan sistem yang sedang berjalan perlu dilakukan tahap perancangan terhadap sistem yang ada dengan memanfaatkan keberadaan sistem yang lama. Dengan sistem yang baru ini diharapkan dapat meningkatkan pelayanan kepada anggota serta dapat membantu karyawan dalam menjalankan tugasnya.

Adapun usulan untuk sistem yang baru ini adalah :

a. Akan dibuat sistem informasi yang mampu untuk menyimpan datadata yang berkaitan dengan akuntansi. Dimana pada sistem yang baru ini bagian keuangan akan dapat melakukan aktivitas dengan cepat dan akurat serta akan dapat menghemat waktu dalam aktivitas Koperasi tersebut, serta data transaksi keuangan Koperasi Anggrek II lebih jelas dan terinci makan laporan keuangan sebelumnya dikembangkan menjadi beberapa laporan.

b. Agar pengolahan data pada Koperasi Anggrek II dapat berjalan dengan akurat, dalam pembuatan sistem ini dioptimalkan dengan memanfaatkan database MySQL untuk menampung seluruh data yang ada pada sistem informasi Koperasi tersebut, dan dalam pelaksanaannya akan digunakan sebuah bahasa pemrograman JAVA untuk melakukan penginputan data yang akan dimasukkan kedalam database Koperasi tersebut.

c. Sistem informasi yang dibuat dapat menghasilkan laporan dengan cepat sehingga akan membantu kinerja dari Koperasi tersebut.
Desain sistem pengelohan data ini terbagi dalam dua tahap yaitu desain sistem secara global dan desain sistem secara terinci. Desain global dilakukan untuk memberikan gambaran umum kepada user mengenai sistem yang akan dirancang, selain itu desain global juga berguna untuk memudahkan dalam melakukan desain terinci.

\section{Desain Global}

Pada desain global ini akan digunakan rancangan sistem secara umum, yaitu dengan menampilkan bentuk jalur perpindahan data dari suatu entity ke entity lainnya. Tujuan dari desain global adalah memberikan gambaran secara umum kepada user tentang sistem yang baru. Rancangan sistem mengidentifikasikan komponenkomponen sistem informasi yang akan didesain secara rinci.

Perancangan sistem yang dilakukan di dalam tahap desain global ini terdiri dari rancangan Aliran Sistem Informasi (ASI) baru, Context Diagram, Data Flow Diagram (DFD) level 0, Entity Relationship Diagram (ERD) dan Struktur Program.

\section{a. Aliran Sistem Informasi (ASI) Baru}

Sistem baru yang dirancang ini adalah usaha untuk menutupi kekurangan dari sistem yang lama. Seperti yang telah disebutkan di atas, kekurangan dari sistem yang lama terletak pada proses kerja dan pengolahan datanya. Jadi, pada sistem yang diusulkan ini perubahan yang dilakukan hanya terletak pada proses kerja tersebut yang dirubah menjadi sistem secara keseluruhan.

Agar data transaksi keuangan Koperasi Anggrek II lebih jelas dan terinci maka 
laporan keuangan sebelumnya dikembangkan menjadi beberapa laporan. Seperti laporan perkiraan, laporan jurnal, laporan neraca saldo dan laporan laba rugi.

b. Context Diagram

Context Diagram adalah gambaran umum tentang suatu sistem yang terdapat di dalam suatu organisasi yang memperlihatkan batasan (boundary) sistem, adanya interaksi antara eksternal entity dengan suatu sistem, serta informasi secara umum mengalir diantara entity dan sistem. Context Diagram ini merupakan alat bantu yang digunakan dalam menganalisa sistem yang akan dikembangkan. Pada Gambar 3.5 dapat dilihat gambaran seluruh input ke sistem dan output dari sistem. Didalam Context Diagram dapat dilihat ada Lima komponen yang berperan di dalam pembuatan sistem informasi akuntansi, yaitu : Pemimpin, Karyawan, dan Bagian Keuangan.

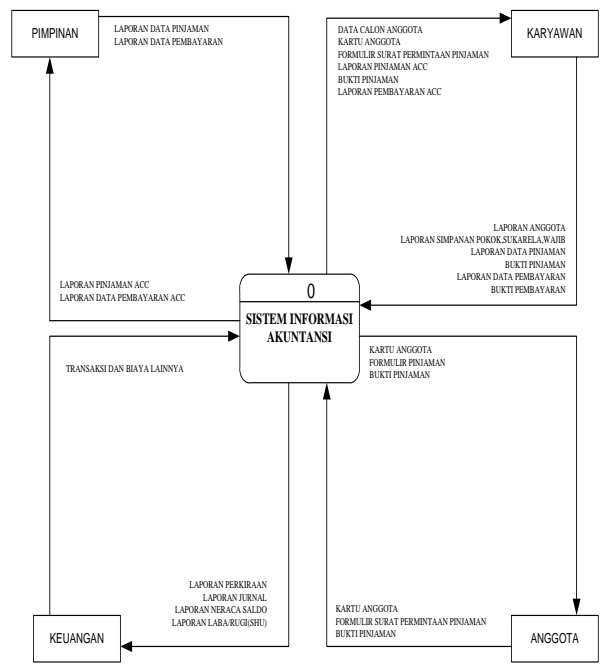

Gambar 4. Context Diagram Data Flow Diagram (DFD) Level 0
Data Flow Diagram menggambarkan sebuah Sistem Informasi yang menitikberatkan pada proses (fokus pada Proses). Dengan mengacu kepada Context Diagram, proses yang terjadi diuraikan ke dalam bentuk Data Flow Diagram (DFD). Untuk lebih jelasnya Data Flow Diagram sistem informasi akuntansi Koperasi Anggrek II dapat digambarkan seperti pada Gambar 5.

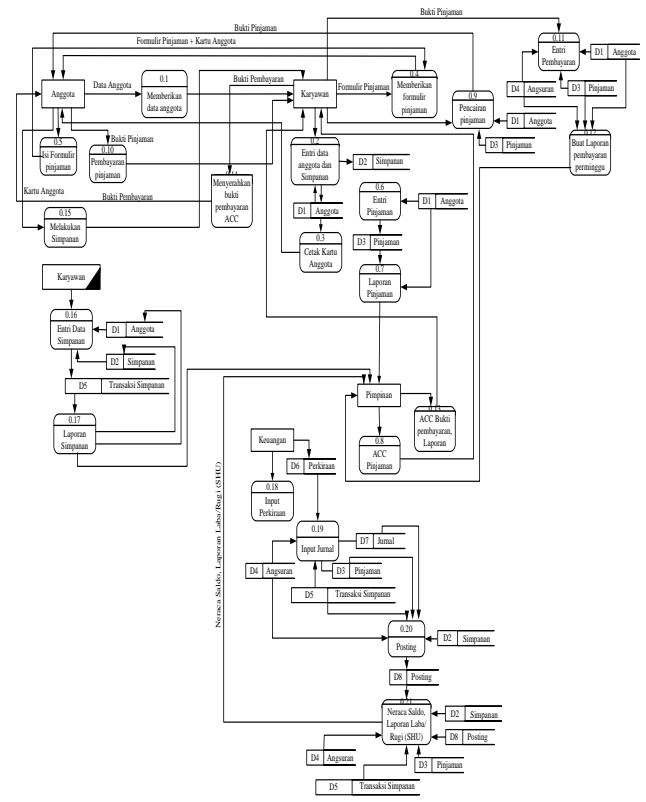

\section{Gambar 5. Data Flow Diagram Entity Relationship Diagram}

$\begin{array}{rrr}\text { Entity } & \text { Relationship } & \text { Diagram } \\ (E R D) & \text { merupakan } & \text { suatu } \\ \text { dokumentasi } & \text { data } & \text { yang }\end{array}$ mengidentifikasikan entity data dan memperlihatkan hubungan yang ada diantara entity tersebut dengan menggunakan atribut key field (Primary Key Atribut) dari masingmasing entity.

Pada gambar ini dijelaskan bahwa setiap entity mempunyai atributnya masing-masing, salah satunya berfungsi sebagai primary key atau sebagai foreign key. Adapun bentuk hubungan dari masing-masing entity dari sistem yang dirancang dapat digambarkan seperti pada Gambar 3.7. 


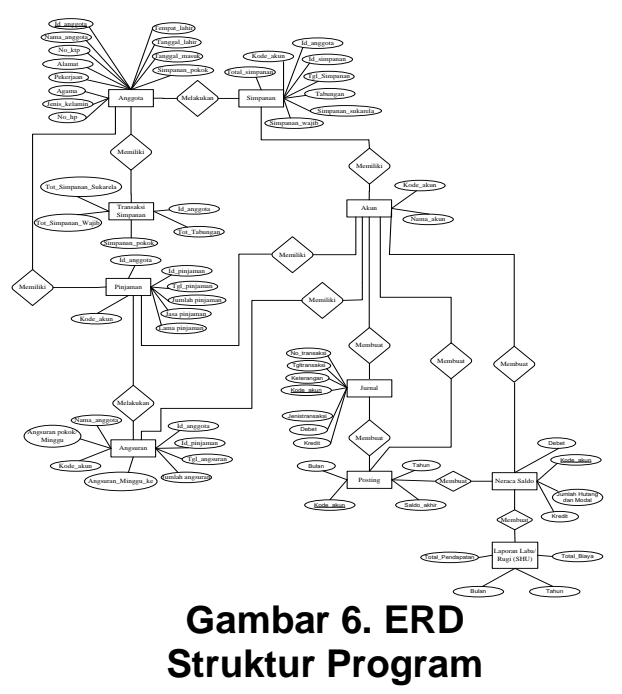

Stuktur Program adalah gambaran dari sebuah rangkaian modul-modul program yang saling terkait satu sama lain yang terlihat dalam proses pengolahan data. Pembuatan struktur program ini dimaksudkan untuk mempermudah dalam memahami keterkaitan modul-modul program dan untuk memperlihatkan jenjang atau hirarki dari program yang dirancang. Dengan demikian dapat dijabarkan urutan kerja dari tiap modul program. Adapun bentuk struktur program dapat digambarkan pada Gambar 3.7,

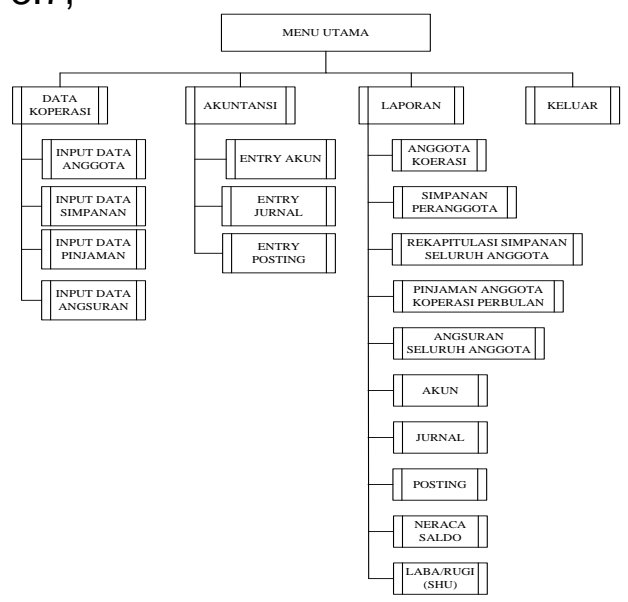

Gambar 3.7 : Struktur Program
HASIL DAN PEMBAHASAN

Pengujian dan Implementasi Sistem

Pengujian merupakan tahap uji coba terhadap sistem yang telah dibuat apakah sistem sudah berjalan dengan benar. Sedangkan implementasi merupakan pengetesan sistem dengan menggunakan data yang sesungguhnya dalam jangka waktu tertentu yang dilakukan oleh analis sistem bersama dengan user.

\section{a. Halaman login}

Halaman login ditampilkan setelah melakukan perintah login.java, dan jalankan dengan menekan tombol keyboard Shift+F6 atau juga bisa mengklik menu Run, dan pilih Run File. Setelah jalan, kemudian isikan username dan password terlebih dahulu sebelum mengklik login. Seperti pada Gambar 8.

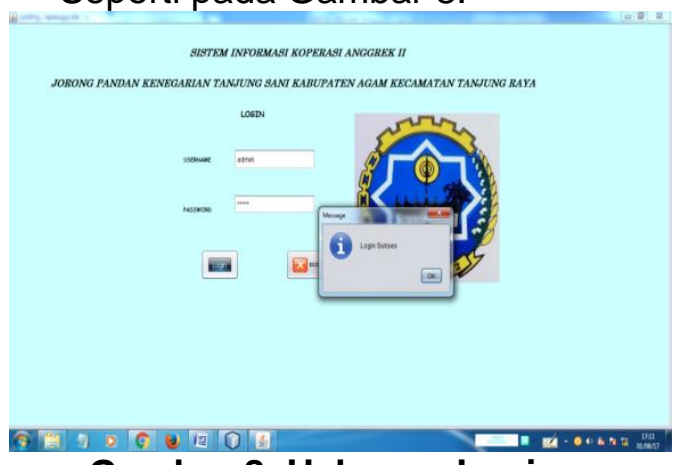

Gambar 8. Halaman Login

\section{b. Halaman Menu Utama}

Halaman Menu Utama akan kita temui setelah selesai melakukan login, dan sebelum masuk ke sub menu yang lain kita bisa mengklik item-item yang tersedia seperti pada Gambar 9. 


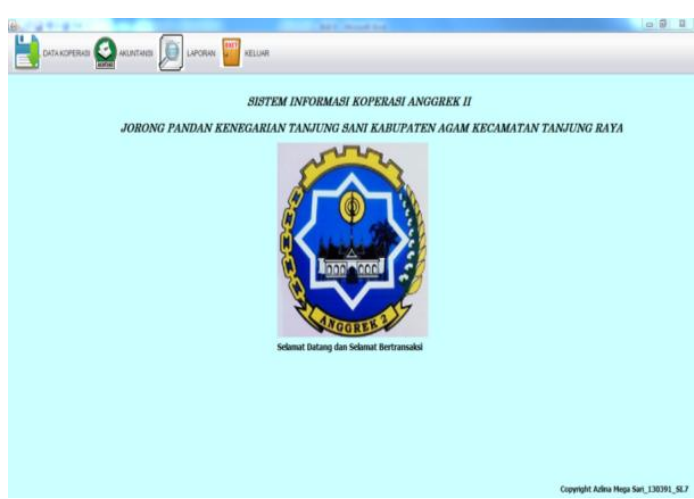

Gambar 9. Halaman Menu Utama

\section{c. Halaman Anggota Koperasi}

Halaman Anggota berfungsi untuk menampilkan informasi tentang data anggota Koperasi. Administrator dapat mengklik menu Laporan dan mengklik sub menu Laporan Anggota sehingga muncul tampilan data anggota seperti pada Gambar 10.

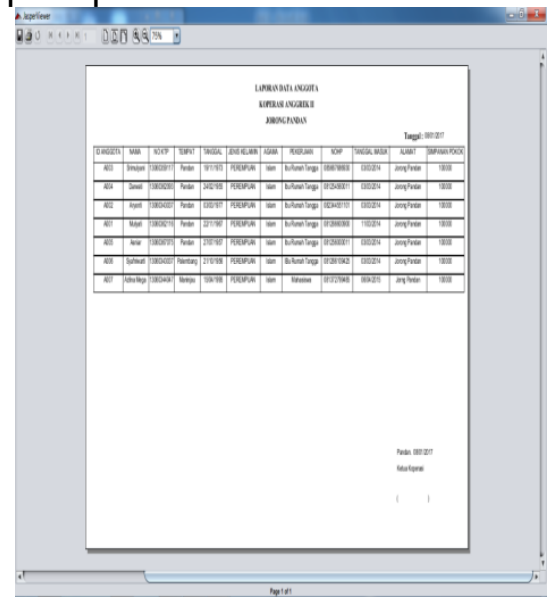

d.

\section{Gambar 10 Halaman Anggota Koperasi}

e. Halaman Simpanan Peranggota Halaman Simpanan Peranggota berfungsi untuk menampilkan informasi tentang data Simpanan peranggota. Administrator dapat mengklik menu Laporan dan mengklik sub menu Laporan Simpanan Peranggota, sehingga muncul tampilan data Simpanan Peranggota seperti pada Gambar 11.

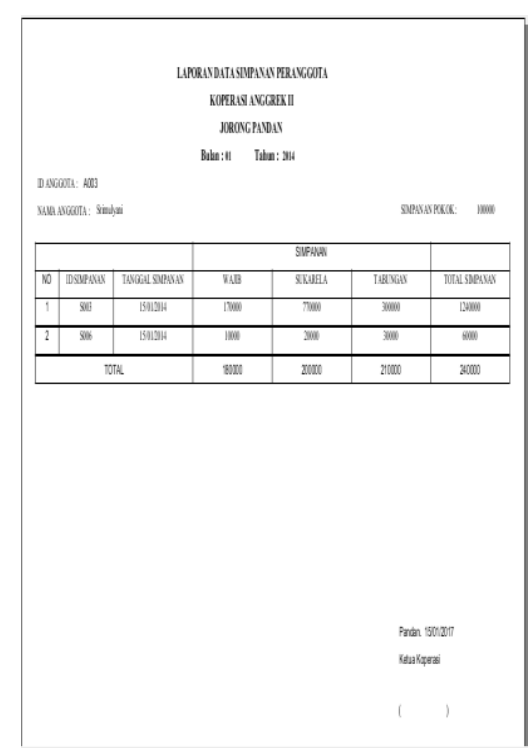

\section{Gambar 11. Halaman Data Simpanan Peranggota}

\section{f. Halaman Rekapitulasi Simapanan Seluruh Anggota} Halaman Rekapitulasi Simpanan Seluruh Anggota berfungsi untuk menampilkan informasi tentang data Rekapitulasi Simpanan Seluruh Anggota. Administrator dapat mengklik menu Laporan dan mengklik sub menu Laporan Simpanan sehingga muncul tampilan data Simpanan Anggota seperti pada Gambar 12.

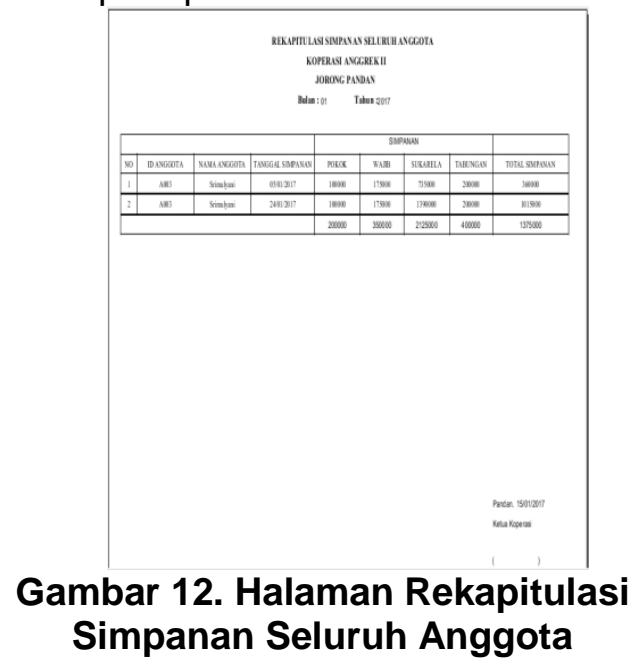




\section{g. Halaman Pinjaman Anggota Koperasi Perbulan \\ Halaman Pinjaman Anggota Koperasi Perbulan berfungsi untuk menampilkan informasi tentang data pinjamanan dalam koperasi. Administrator dapat mengklik menu Laporan dan kemudian mengklik sub menu Laporan Pinjaman sehingga muncul tampilan data pinjamanan anggota seperti pada Gambar 13.}

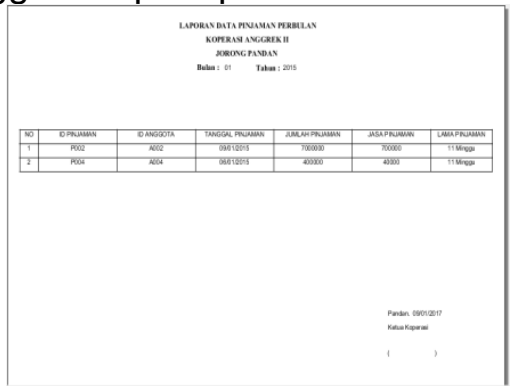

Gambar 13. Halaman Pinjaman Anggota Koperasi Perbulan

\section{h. Halaman Angsuran Seluruh Anggota}

Halaman Angsuran Seluruh Anggota berfungsi untuk menampilkan informasi tentang data angsuran seluruh anggota. Administrator dapat mengklik menu Laporan dan kemudian mengklik sub menu Laporan Angsuran sehingga muncul tampilan data angsuran anggota seperti pada Gambar 14.

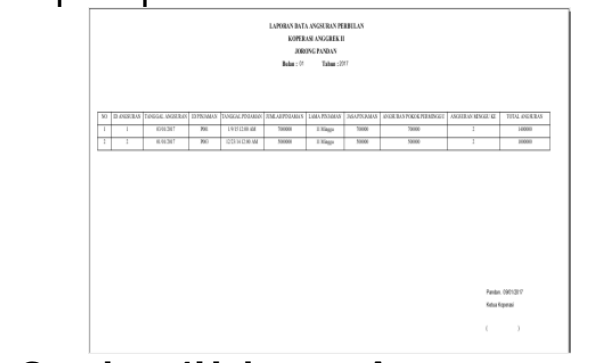

\section{Gambar 4Halaman Angsuran Seluruh Anggota}

\footnotetext{
KESIMPULAN

Dari uraian yang telah dikemukakan pada bab-bab sebelumnya berdasarkan hasil
}

penelitian yang telah dilakukan pada Koperasi Anggrek II Jorong Pandan Kenegarian Tanjung Sani Kabupaten Agam, maka dapat diambil beberapa kesimpulan antara lain :

1. Dengan didukung penggunaan komputer dan penerapan Sistem Informasi Akuntansi Koperasi Anggrek II mampu menghasilkan informasi yang tepat dan akurat.

2. Dengan digunakannya bahasa pemrograman JAVA dan database MySQL pada proses pengolahan data keuangan Koperasi Anggrek II membantu meningkatkan kinerja dan menghasilkan informasi yang akurat.

3. Dalam melakukan analisa sistem informasi akuntansi dan pengolahan data keuangan, dapat memberi informasi atau laporan yang akurat dalam mengambil keputusan yang tepat, sehingga masalahmasalah yang berhubungan dengan analisa sistem informasi keuangan pada Koperasi Anggrek II Jorong Pandan Kecamatan Tanjung Raya Kabupaten Agam dapat teratasi.

4. Sistem yang lama tidak seluruhnya dibuang atau digantikan dengan sistem yang baru karena dalam menjalankan sistem yang baru ini masih memerlukan sistem yang lama.

\section{DAFTAR PUSTAKA}

1] Sukadi, Atikah, Hayyu Ratna. Sistem Informasi Pinjam pada Koperasi Wanita Putri Harapan Desa Jati Gunung Kecamatan Tulakan. Indonesian Journal on Networking and Security (IJNS) Volume 2 No 4 - Oktober 2013 - ISSN: 2301-5700 http:/ijns.org. 
[2] Tungadi, Astrid Lestari. Sistem Informasi Akuntansi pada Koperasi Universitas Atma Jaya Makassar. Jurnal Tematika Vol. 1 No 2, September 2013, ISSN: 23033878.

[3] Anggraeni, Nova, Retnadi, Eko, \& Kurniawati, Rina. Perancangan Sistem Informasi Simpan Pinjam di KUD Mandiri Bayongbong.

http://jurnal.sttgarut.ac.id - ISSN : 2302-7339 Vol. 09 No. 05 2012.

[4] Agustini, Dwi Made Ni, Bagia , I Wayan, \& Yudiaatmaja, Fridayana. Pengaruh Perputaran Kas dan Piutang Terhadap Rentabilitas Ekonomis pada Koperasi. e-Journal Bisma Universitas Pendidikan Ganesha Jurusan Manajemen (Volume 2 Tahun 2014).

[5] Karjono Albertus, Fakrina Amelia Falah. Pengaruh Perputaran Kas dan Perputaran Kas dan Perputaran Piutang Terhadap Rentabilitas Ekonoi pada KPRI di Lingkungan BKN. ESENSI Volume 15 No.2 / Agustus 2012.

[6] Pratama, Eka Agus Putu I, Sisem Informasi dan Implementasinya, Penerbit Informatika Bandung 2014.

[7] Sutabri, Tata, Analisis Sistem Informasi. Yogyakarta:Andi Offset, 2012.

[8] Krismiaji, M.Sc., Ak., CA. Dr., Sistem Informasi Akuntansi (edisi keempat), Yogyakarta: Krismiaji, 2015.

[9] Yakub, Pengantar Sistem Informasi, Penerbit Graha Ilmu.Yogyakartan, 2012.

[10] Abdul Kadir,Algoritma \& Pemrograman Menggunakan Java, Penerbit Andi,Yogyakarta, 2012.

[11] Hidayatullah, Priyanto, Kawistara,khairul Jauhari, Pemrograman WEB, Informatika Bandung, 2014. 